\title{
Morphological and cultural characterization of Phyllosticta zingiberi (Ramkr.) causing leaf spot disease of ginger
}

\author{
Barun Rai, Sekhar Bandyopadhyay*, Avisak Thapa, Adeetya Rai and Deewakar Baral \\ Department of Plant Pathology, Uttar Banga Krishi Viswavidyalaya, Pundibari, Coochbehar, 736165 (West Bengal), INDIA \\ *Corresponding author. E-mail: sekhar29@gmail.com
}

Received: May 22, 2016; Revised received: April 7, 2017; Accepted: August 9, 2017

Abstract: Isolation of ginger (Zingiber officinale) leaf spot pathogen form the UBKV farm field was done in the laboratory. The isolated pathogen was identified as Phyllosticta zingiberi on the basis of morphological characters as documented in taxonomic keys. The microscopic observation revealed that the pycnidia were globose to sub-globose with dark brown colour measuring $124.16 \mu \mathrm{m} \times 2.35 \mu \mathrm{m}$ in average. The pycnidio spores were hyaline, oval to bullet shaped, monoguttulate measuring $4.02 \mu \mathrm{m} \times 2.35 \mu \mathrm{m}$ in average. Among the different media tested for growth highest growth was recorded in Oat meal agar $\left(26.44 \mathrm{~cm}^{2}\right)$ followed by malt extract agar $\left(24.04 \mathrm{~cm}^{2}\right)$ which was statistically at par. The temperature of $25^{\circ} \mathrm{C}$ favoured maximum growth $\left(24.20 \mathrm{~cm}^{2}\right)$. However, higher sporulation was observed in $30^{\circ} \mathrm{C}$. Among the different carbon source tested, mannitol supported the highest growth of the pathogen $\left(27.67 \mathrm{~cm}^{2}\right)$.

Keywords: Ginger, Leaf spot, Mannitol, Phyllosticta zingiberi, Pycnidia

\section{INTRODUCTION}

Ginger (Zingiber officinale Rosc.) is an important tropical spice belonging to the family Zingiberaceae. The plant possesses a combination of many attributes and properties there of making its utility diverse. Ginger is prone to many serious diseases, which are caused by fungal, bacterial and nematode infections. Among them the major diseases causing hindrance in ginger production includes soft rot (Pythium spp.), yellows (Fusarium spp.), Rhizome rot complex (fungi, nematode/ insect interactions), leaf spot (Phyllosticta sp.) and storage rots (Pythium spp., Fusarium spp. etc.) (Rajan et al., 2002; Senapati and Ghose, 2005). Leaf spot diseases appears and remains prevalent during the growth period of the crop and may have little or severe effect depending on the environmental conditions. The major leaf spot diseases are Phyllosticta, Helminthosporium, Cercospora, Pyricularia, Rhizoctonia Septoria leaf spots, etc. Among these Phyllosticta leaf spot caused by Phyllosticta zingiberi Ramakr. is considered to be the most destructive appearing in mild or severe form in all the ginger growing tracts of the country (Sood and Dohroo, 2005; Singh, 2015). During the recent years the disease has become significantly important due to severe leaf spotting which destroys the chlorophyllous tissues causing significant reduction in yield (Iyer, 1988; Singh et al., 2000). Sarma et al. (1994) has recorded 13-66 percent yield loss depending upon its severity. Sood and Dohroo (2005) recorded 48.3 percent loss in mother rhizome and 65.9 percent in yield of fresh rhizome when the severity of $P$. zingiberi was 58.3 percent. Singh (2015) recorded nearly $80 \%$ disease incidence in untreated control plot infected with leaf spot disease of ginger and lowest disease of $21.3 \%$ in $0.1 \%$ carbendazim treated plots. Again Bandyopadhyay et al. (2015) recorded PDI of 34.24 of leaf spot disease of ginger in untreated control plots whereas 3 sprayings with $0.1 \%$ hexaconazole produced the lowest PDI of 12.12 So keeping in.view of the losses caused by leaf spot pathogen and sparse information available on different aspects of the disease an attempt was made to study the morphological and cultural characters of $P$. zingiberi causingleaf spot disease of ginger.

\section{MATERIALS AND METHODS}

Isolation, identification and pathogenicity: Isolation of the pathogen was done on potato dextrose agar (PDA) medium from the diseased leaf samples collected from the UBKV farm field. The inoculum of the isolated fungus was sprayed on healthy leaves of ginger plant raised in green house condition for proving pathogenicity (Ramakrishnan, 1942).

Morphological characters: The morphological characters of $P$. zingiberi were studied with respect to colour, shape and size of pycnidia and pycnidiospores. For this purpose, fourteen days old culture of isolate grown on PDA was studied. For pycnidial and conidial dimensions fifty pycnidia and pycnidiospores were selected for study at random from slides. The study was done with the help of Olympus CX41 model 
microscope fitted with Moticam 3.0 MP. The captured images were measured microscopically with the help of Motic image software and average dimensions were worked out.

\section{Cultural characters (Growth parameters)}

Suitable media for growth: In order to find out a suitable media for the growth of the pathogen, six different media i.e. Potato dextrose agar, Czapek-Dox agar, Oat meal agar, Corn meal agar, Potato carrot agar and Malt extract agar were selected. Sood (2002) studied the growth of $P$. zingiberi in different agar media in Himachal Pradesh. Different agar media were also used by Zimowska (2013) for the growth of Phyllosticta plantaginis. Growth of Phyllosticta musarum causing leaf spot disease of banana was measured in different agar media by Ravikumara in 2011. The pathogen was inoculated on each medium and incubated with three replications at $25 \pm 1^{\circ} \mathrm{C}$. The data pertaining to radial growth of the pathogen i.e colony diameter $(\mathrm{cm})$ were recorded after 8 days. Then the growth was converted to area $\left(\mathrm{cm}^{2}\right)$ by the help of the formula $\mathrm{A}=\pi \mathrm{r}^{2}$.

Optimum temperature for growth: The effect of temperature on vegetative growth was investigated by inoculating $9 \mathrm{~mm}$ discs of the fungal culture on petriplates containing PDA media. This type of study of mycelial growth of $P$. zingiberi in different temperatures was done by Cerezine et al. (1995). Growth of $P$. plantaginis in different temperatures was also studied by Zimowska (2013). Growth of $P$. musarum was studied in 6 different temperatures like 10, 15, 20, 25, 30, $350 \mathrm{C}$ and room temperature by Ravikumara in 2011 . The cultures were incubated in different temperature i.e. $20,25,30$ and $35^{\circ} \mathrm{C}$ with three replications. The radial growth of the pathogen i.e colony diameter $(\mathrm{cm})$ was recorded after 8 days. Then the growth was converted to area $\left(\mathrm{cm}^{2}\right)$ by the help of the formula $A=\pi r^{2}$.

Effect of different carbon source on growth: The fungus was grown in $90 \mathrm{~mm}$ petriplates containing 20 $\mathrm{ml}$ media amended with different carbon sources such as cellulose, dextrose, fructose, maltose, starch and sucrose. Growth of Phyllosticta on different carbon sources was done by Tandon and Bilgrami (1957) and also by Sood (2002). Seven different carbon sources were employed to identify the best carbon that could support good growth and development of $P$. musarum (Ravikumara, 2011). The remaining procedure of plating, inoculation, incubation and recording radial growth of the fungus was same as described earlier.

\section{RESULTS AND DISCUSSION}

The pure culture obtained from the diseased leaves of ginger showing characteristic symptoms of leaf spot was identified as $P$. zingiberi Ramakr. on the basis of morphological characters as documented in taxonomic keys (Ramakrishnan, 1942; Sood, 2002). Further pathogenicity testing proved the pathogenic behaviour of the fungus. The wounded leaves sprayed with fungal suspension (Ramakrishnan, 1942) started producing symptoms from fourth day onwards; initially the spots were small, yellow, round to oval. At later stage the spots became enlarged with irregular spots having white papery centre and yellow halo (Sood, 2002). The colony of the fungus when grown on PDA showed slow growth with smooth surface having regular margin. The colony colour exhibited a pattern of light grey at the margins with olivaceous green zonation. Mycelium was dense, suppressed and light grey in colour. Hyphae of the fungus were hyaline, aseptate and having irregular swellings. Pycnidia produced by the isolate were dark brown, ostiolate, globose to sub-globose measuring $124.16 \mu \mathrm{m} \times$ $122.96 \mu \mathrm{m}$ in average. Pycnidiospores were also abundantly released in cirrhus which were hyaline oval to bullet shaped, aseptate, unigutttulate and measured $4.02 \mu \mathrm{m} \times 2.35 \mu \mathrm{m}$ in average (Table 1) which is in accordance with the findings of Ramakrishnan, 1942; Sohi et al., 1964; Shukla and Haware, 1972; Sood, 2002. Ostiolate pycnidia of 63-82 $\mu \mathrm{m}$ in size and aseptate or single celled, hyaline, oval to ellipsoidal conidia with a size of 5.2-5.5 $\mu \mathrm{m} \times 1.8-2.2 \mu \mathrm{m}$ was recorded by Zimowska (2013) in $P$. plantaginis. In $P$. musarum causing leaf spot of banana, the pycnidia were more or less spherical, 46-96.3 $\mu \mathrm{m}$ in diameter on average and the pycnidiospores were hyaline, one celled, sub globose to ellipsoidal and measure 7.5-15 $\mu \mathrm{m} \times 2.5-5 \mu \mathrm{m}$ (Ravikumara, 2011).

The results of various media evaluated for the growth of the pathogen is presented in Table 2. It was observed that highest growth was recorded in Oat meal agar $\left(26.44 \mathrm{~cm}^{2}\right)$ which was statistically at par with malt extract agar $\left(24.04 \mathrm{~cm}^{2}\right)$ and potato dextrose $\left(22.04 \mathrm{~cm}^{2}\right)$ whereas lowest growth was observed in corn meal agar $\left(9.08 \mathrm{~cm}^{2}\right)$. This result matches with the former research done by Sood, 2002 who has reported maximum growth in PDA which was statistically at par with malt extract agar. Zimowska (2013) also supports our findings and reported that

Table 1. Morphological measurement details of $P$. zingiberi.

\begin{tabular}{|c|c|c|c|c|c|c|c|c|c|}
\hline \multicolumn{5}{|c|}{ Pycnidia } & \multicolumn{5}{|c|}{ Pycnidiospores } \\
\hline Average & $\begin{array}{l}\text { Highest } \\
\text { length }\end{array}$ & $\begin{array}{l}\text { Lowest } \\
\text { length }\end{array}$ & $\begin{array}{l}\text { Highest } \\
\text { width }\end{array}$ & $\begin{array}{l}\text { Lowest } \\
\text { width }\end{array}$ & Average & $\begin{array}{l}\text { Highest } \\
\text { length }\end{array}$ & $\begin{array}{l}\text { Lowest } \\
\text { length }\end{array}$ & $\begin{array}{l}\text { Highest } \\
\text { width }\end{array}$ & $\begin{array}{l}\text { Lowest } \\
\text { width }\end{array}$ \\
\hline $\begin{array}{l}124.16 \mu \mathrm{m} \\
\times 122.96 \\
\mu \mathrm{m}\end{array}$ & $\begin{array}{l}200.63 \\
\mu \mathrm{m}\end{array}$ & $66.95 \mu \mathrm{m}$ & $\begin{array}{l}198.55 \\
\mu \mathrm{m}\end{array}$ & $\begin{array}{l}66.95 \\
\mu \mathrm{m}\end{array}$ & $\begin{array}{l}4.02 \mu \mathrm{m} \\
\times \\
2.35 \mu \mathrm{m}\end{array}$ & $5.55 \mu \mathrm{m}$ & $3.13 \mu \mathrm{m}$ & $3.16 \mu \mathrm{m}$ & $\begin{array}{l}1.16 \\
\mu \mathrm{m}\end{array}$ \\
\hline
\end{tabular}


Barun Rai et al. / J. Appl. \& Nat. Sci. 9 (3): 1662 -1665 (2017)

malt agar medium and the media made with an extract from ribwort leaves are recommended for use in characteristic observations of $P$. plantaginis as very fast sporulation occurs here. Good colony growth with a diameter of $74.67 \mathrm{~mm}$ and $68.17 \mathrm{~mm}$ was achieved in Potato Dextrose Agar and Oat Meal agar media respectively by $P$. musarum (Ravikumara, 2011).

The mycelial growth of the pathogen grown in different temperatures after 8 days of incubation is presented in Table 3. It was observed that the temperature of $25^{\circ} \mathrm{C}$ favoured maximum growth $\left(24.20 \mathrm{~cm}^{2}\right)$ whereas temperature of $35^{\circ} \mathrm{C}$ recorded lowest growth of $P$. zingiberi on PDA however, higher sporulation was observed in $30^{\circ} \mathrm{C}$. Higher sporulation in higher temperature may be due to the fact that the fungus is exposed to stress condition in higher temperature and it is a common fact that in stress situations fungus produces more number of spores to overcome the stress. The results are in conformity with the works of Ramakrishnan, 1942; Cerezine et. al, 1995 and Sood, 2002 who have reported $25^{\circ} \mathrm{C}$ to be the best temperature regimen for the mycelial growth of the pathogen. Similar type of result was found by Zimowska (2013) who reported that $20^{\circ} \mathrm{C}$ to $28^{\circ} \mathrm{C}$ was the optimal temperature for the formation of pycnidia and conidia of $P$. plantaginis. Highest growth of $P$. musarum was recorded in $300 \mathrm{C}$ which is closely followed by $250 \mathrm{C}$ (Ravikumara, 2011).

Table 2. Effect of different agar media on the growth of $P$. zingiberi.

\begin{tabular}{lc}
\hline Agar medium & $\begin{array}{c}\text { Growth in area }\left(\mathbf{c m}^{\mathbf{2}}\right) \text { at } 192 \\
\text { hours }\end{array}$ \\
\hline Cazpek-Dox & 15.87 \\
Corn meal & 9.08 \\
Malt extract & $24.04^{*}$ \\
Oat meal & $26.44^{*}$ \\
Potato carrot & 12.94 \\
Potato dextrose & $22.04^{*}$ \\
SEm \pm & 1.45 \\
C.V $(\%)$ & 13.67 \\
CD $(\mathrm{P}=0.05)$ & 4.58 \\
\hline
\end{tabular}

Figures represented by $*$ do not differ significantly

Table 3. Effect of different temperature regimes on growth of $P$. zingiberi using Potato Dextrose Agar medium

\begin{tabular}{lc}
\hline Temperature $\left({ }^{\mathbf{0}} \mathbf{C}\right)$ & $\begin{array}{c}\text { Growth in area }\left(\mathbf{c m}^{\mathbf{2}}\right) \text { at } \mathbf{1 9 2} \\
\text { hours }\end{array}$ \\
\hline 20 & $14.20^{*}$ \\
25 & 24.2 \\
30 & $10.67^{*}$ \\
35 & 2.45 \\
$\mathrm{SEm} \pm$ & 1.26 \\
$\mathrm{C} . \mathrm{V}(\%)$ & 17 \\
$\mathrm{CD}(\mathrm{P}=0.05)$ & 4.37 \\
\hline
\end{tabular}

Figures represented by $*$ do not differ significantly
Table 4. Effect of different carbon source on growth of $P$. zingiberi using Potato Dextrose Agar medium

\begin{tabular}{lc}
\hline Carbon Sources & $\begin{array}{c}\text { Growth in area }\left(\mathbf{c m}^{2}\right) \text { at } \mathbf{1 9 2} \\
\text { hours }\end{array}$ \\
\hline Cellulose & 14.44 \\
Fructose & $23.10^{*}$ \\
Maltose & $23.78^{*}$ \\
Mannitol & $27.67^{*}$ \\
Starch & 18.8 \\
Sucrose & $27.29^{*}$ \\
Dextrose & $24.20^{*}$ \\
SEm \pm & 2.2 \\
C.V $(\%)$ & 9.13 \\
CD $(\mathrm{P}=0.05)$ & 3.69 \\
\hline
\end{tabular}

Figures represented by $*$ do not differ significantly

The carbon source required for the fungal mycelium to attain maximum growth was found to be mannitol $\left(27.67 \mathrm{~cm}^{2}\right)$ followed by sucrose $\left(27.29 \mathrm{~cm}^{2}\right)$ and dextrose $\left(24.20 \mathrm{~cm}^{2}\right)$ which were statistically at par with each other and the lowest growth of $14.44 \mathrm{~cm}^{2}$ was recorded in cellulose (Table 4). The findings corroborates with the study of Sood, 2002 who recorded maximum dry weight of mycelium in mannitol. Among different carbon sources tested, highest growth of $P$. musarum was recorded in glucose which is followed by glycerol, fructose and sucrose (Ravikumara, 2011).

\section{REFERENCES}

Bandyopadhyay, S., Rai, B. and Debnath, A. (2015). Efficiency of different fungicides against leaf spot disease of ginger. The Bioscan. (Supplement on Plant Pathol ogy) 10 (4): 1783-1786

Cerezine, P.C., Olinisky, I.A., Bittencourt, M.V.L. and Valerio Filho, W.V. (1995). Phyllosticta leaf spot on ginger, cultural characterization of the pathogen and effect of chemical treatments on disease control in Morretes, Parana State Brzil. Pesquia Agropecnasi Brasileira. 30: 477-487.

Iyer, R. 1988. Diseases of ginger. In: Raychaudhary S.P. andVerma J.P. (Eds.). Rev. Trop. Plant Pathol., Today and Tomorrow Publication, New Delhi. 4: 251-288.

Rajan, P. P., Gupta, S.R., Sarma, Y.R. and Jackson, G.V.H. (2002). Diseases of ginger and their control with Trichodermah arzianum. Indian Phytopath., 55 (2): 173 $-177$

Ramakrishnan, T.S. (1942). A leaf spot disease of Zingiberofficinale caused by Phyllosticta zingiberi. Proc. Indian Acad. Sci. 15: 167-171.

Ravikumara, B.M. (2011). Studies on Leaf Spot Diseases of Banana caused by Phyllosticta musarum (Cke) Van der Aa and Helminthosporium torulosum (Sydow) Ashby. M. Sc. Thesis, University of Agricultural Sciences, GKVK Campus, Bangalore-560065

Senapati, A.K. and Ghose, S. (2005). Screening of ginger varieties against rhizome rot disease complex in eastern ghat high land zone of Orissa. Indian Phytopath. 58 (4): 437-439. 
Shukla, B.N. and Haware, M.P. (1972). Phyllosticta leaf spot of ginger (Zingiber officinale) in Madhya Pradesh. Indian J. Mycol. Plant Pathol. 2: 93

Sohi, H.S., Jain, S.S., Sharma, S.L. and Verma, B.R. (1964). New records of plant diseases from Himachal Pradesh. Indian Phytopath., 17: 42-45.

Sood, R. (2002). Studies on leaf spot of ginger caused by Phyllosticta zingiberi Ramakr. M.Sc. Thesis, Dr. Y.S. Parmar University of Horticulture and Forestry, Nauni, Solan, India.

Sood, R and Dohroo, N.P. (2005). Epidemiology and management of leaf spot of ginger in Himachal Pradesh. Indian Phytopath., 58(3): 282-288.

Singh, A.K. (2015). Efficacy of fungicides for the control of leaf spot disease of ginger under the field conditions of
Chhattisgarh (India). African J. of Agricultural Research, 10 (11): 1301-1305.

Singh, A.K., Edison, S., Shashank and Yadav, R.K. (2000). Reaction of ginger germplasm to Phyllosticta zingiberi under field conditions. Indian Phytopath., 53: 210-212.

Sarma, Y.R., Anand Raj, M. and Venugopal, M.N. (1994). Diseases of Spice crops. In: Advances in Horticulture- Plantation and Spice crops, Part 2 (1994), (K.L. Chadha and P. Rethinam, eds.) Malhotra Publishing House, New Delhi, Vol. 10:1015-1057.

Tandon, R.N. and Bilgrami, K.S. (1957). Assimilation of disaccharides by some fungi causing leaf spot disease. Proc. Indian. Acad. Sci. Soc., 46: 274-284.

Zimowska, B. (2013). Occurrence and characterization of Phyllostictaplantaginis. J Plant Physiol. Pathol., 1: 1. doi:http://dx.doi.org/10.4172/jppp.1000101 